SHEs: Conference Series 4 (3) (2021) $17-31$

\title{
History and Types of Education in Indonesia and Its Impact on Economic Growth
}

\author{
Patni Ninghardjanti, Wiedy Murtini, Aniek Hindrayani, Khresna Bayu Sangka
}

Universitas Sebelas Maret

ning@staff.uns.ac.id

\author{
Article History \\ accepted 31/01/2021 approved 28/01/2021 published 31/03/2021
}

\begin{abstract}
s
The Nawacita program framework, the Government of Indonesia is trying to improve the quality and equity of the national education system by increasing the education sector national budget to 500 trillion rupiah, and appointing the Chief Executive Officers (CEO) of the Gojek Internet Start-up company, in order to boost up the program outcome by using Information Technology (IT) as the main gap bridge in the education sectors. The unequal access to the education level in the formal, informal and non-formal education clusters is emphasizes if the education sectors problems is complex as the development problem. The government trying to tackling that problem by developing the suitable curriculum, and maximization of the use of IT in the education sectors to improve the quality and equity for the education. In this research, the correlation between the rapid development of education sectors and the impact to the national economy is analyzed by using the Solow models which said if the investment of human capital, including to the education sectors is one of the main bridge to achieve the status as advanced nation. This research is concluded if the formal education sector have direct and significant impact to the economic sector, then the informal and non-formal educations sectors act as supporting unit in order to achieve the quality and equity, in order to improve the education access.
\end{abstract}

Keywords: Education, Information Technology (IT), Quality and Equity

\begin{abstract}
Abstrak
Kerangka program kerja Nawacita, pemerintah Republik Indonesia mencoba untuk meningkatkan kualitas dan kesetaraan akses dari pendidikan nasional dengan meningkatkan anggaran sektor pendidikan menjadi sebesar 500 Triliun rupiah, dan menunjuk direktur utama dari sebuah perusahaan rintisan internet, Gojek, untuk mengakselerasi capaian tersebut dengan memanfaatkan Teknologi Informasi (TI) sebagai penjembatan utama dalam hal aksesbilitas di sektor pendidikan. Ketidaksetaraan akses dalam pendikan formal, informal dan non formal mempertegas bahwa permasalahan dalam bidang pendidikan sangat kompleks sebagaimana permasalahan dalam bidang pembagunan nasional. Pemerintah mencoba mengatasi permasalahan tersebut dengan mengembangkan kurikulum yang sesuai, serta memaksimalkan peran Teknologi Informasi untuk meningkatkan kualitas dan kesetaraan dalam bidang pendidikan. Dalam penelitian ini, korelasi antara pembangunan masif di bidang pendidikan dan pengaruhnya terhadap perekonomian nasional dianalisa menggunakan model solow, yang menyatakan bahwa investasi terhadap sumber daya manusia, khususnya melalui pendidikan adalah salah satu cara utama untuk menuju negara maju. Hasil analisa menyatakan bahwa peningkatan kualitas dan aksesbilitas pada pendidikan formal memiliki dampak yang signifikan terhadap pertumbuhan ekonomi, lalu pendidikan informal dan non formal dapat disimpulkan sebagai faktor pendukung untuk mencapai kualitas dan kesetaraan dalam bidang pendidikan dalam rangka mencapai aksesbilitas yang lebih baik.

Kata kunci: Pendidikan, Teknologi Informasi (TI), Kualitas dan Ekuitas
\end{abstract}

Social, Humanities, and Education Studies (SHEs): Conference Series https://jurnal.uns.ac.id/shes

p-ISSN 2620-9284 e-ISSN 2620-9292

This work is licensed under a Creative Commons Attribution-ShareAlike 4.0 International License. 


\section{INTRODUCTION}

Education is one of the main concern in the current government development plan. The development plan draw higher urgency and attention to the education sectors under the vision of "Advanced Indonesian Superior Human Resources". In order to achieve that vision, according to the Nawacita, that has been described by President Joko Widodo, there are 2 (two) important points that are being developed, which are to improve and to equalize the quality of the national education. The government efforts to improve the quality of the national education is showed by increasing the education sector budget to more than 540 trillion rupiah for the 2020 fiscal year, and to improve education equity is showed by the policies to maximize the use of IT-based educational facilities, by appointing the Chief Executive Officer (CEO) of an Indonesian Startup which providing transportation and online payment services, Nadiem Makarim who is considered competent to lead the Ministry of Education. His competency has proven by bringing "Gojek" as a small start-up company which he has built, to a unicorn company with a valuation of more than 11 trillion rupiah, and national covered services only in 5 (five) years.

The appointment of Nadiem Makarim itself seems to imply that equity in education is an absolute requirements to achieve advanced Indonesia in the future. The equity in education, is developed by the government by implementing the use of Information Technology (IT). The use of Information Technology (IT) for education purposes applied in the form of a Palapa ring service system as a national internet backbone, which streched from Sabang to Merauke. That services has just been inaugurated by the President of Indonesia, Mr. Jokowi Dodo, at the end of October 2019. Hopefully, the use of Information Technology (IT) to supporting the equity education in Indonesia, can creating cheap and accessible education to all member of society (Haller et al., 2013; Hepp et al., 2004; Kurilovas et al., 2014; Menolli, 2015; Saadé et al., 2012; Stošić \& Stošić, 2015; Zhang et al., 2013).

Then, how is the relationship between the education and the economy sectors? The answer to this question cannot be separated from the problem of development. The concept of development in the socio-economic field varies greatly depending on the context of its use. Economists develop development theories based on the production capacity of human labor in the development process, which is then known as investment in human capital (Schultz, 1961). This concept basically assumes that human beings are a form of capital or other forms of capital, similar to machines, technology, land, money and materials. Humans as human capital are reflected in the form of knowledge, ideas (ideas), creativity, skills, and work productivity (Cohendet et al., 2011; Faggian et al., 2017; Sözbilir, 2018; Storper \& Scott, 2009). Unlike other forms of capital which are only treated as tools, this human capital can invest itself through various forms of investment, (Cailhol et al., 2013; Ingham, 2007) for example formal / informal education, work experience, health, or nutrition, and even migration.

In general, it can be stated that the main factor that supports the development process is the level of society education (Boon et al., 2018; Ployhart et al., 2014; Wright \& Mcmahan, 2011). In this process, based on the consideration, can be concluded if the most efficient way to carry out the national development of a country, it's to increasing the capacity of the society by providing better education. 
The theory of Human Capital assumes that formal education is one of the most important instruments for producing high productivity societies (Schultz, 1961). The higher the education of the society, means the higher productivity level of the society (Abel \& Gabe, 2011; Benos \& Karagiannis, 2016; Bonaccorsi et al., 2006; Ghulam \& Mousa, 2019; Soukiazis \& Antunes, 2011). In the development process, the human capital theory must have at least two mandatory requirements, which are the efficient use of technology and the availability of the human resources who manage and / or use the technology. Human resources are generated through the educational process. This is why the human capital theory believes that investment in education is an investment in order to increase the productivity of society.

The problem lies in the extent to which education affects the process of economic development in a country? Cases in several countries indicate this, for example in Africa (Ghana, Kenya, and Nigeria) and in Asia (Korea, Japan, Hong Kong, Singapore, and Malaysia). By referring to experiences in these countries it is important to examine the extent to which the same phenomenon can be applied in Indonesia. This is important considering that Indonesia is currently experiencing a process of imbalance between the economy and education, which is shown by the relationship between education levels and labor force participation and unemployment.

This paper aims to examine how the non-formal, formal and informal aspects of education can influence economic development in the Indonesian context and how the history of education from the time of independence to the present.

\section{DISCUSSION}

\section{Development of Education in Indonesia}

The development of education as one of the driving factors for economic growth cannot be separated since the establishment of the Indonesian state. The important role of education has been recognized with certainty by the founders of the Indonesian nation, since Indonesia's independence, an education curriculum has been developed. The curriculum itself can be defined as an arrangement of subjects / teaching subjects which arranged to facilitate the teaching and learning process to achieve certain academic / practical goals. Since the independence era to present, 3 (three) curriculum development method that has always been applied, consists of the process to design, development, implementation, monitoring, evaluation and review to achieve an effective curriculum, in order to increase the quality of human resources as an important factor in economic growth. On the other hand, according to Sri Wahyuni (2016), the most effective method to describe the history of a country's education, is to study the curriculum itself. 


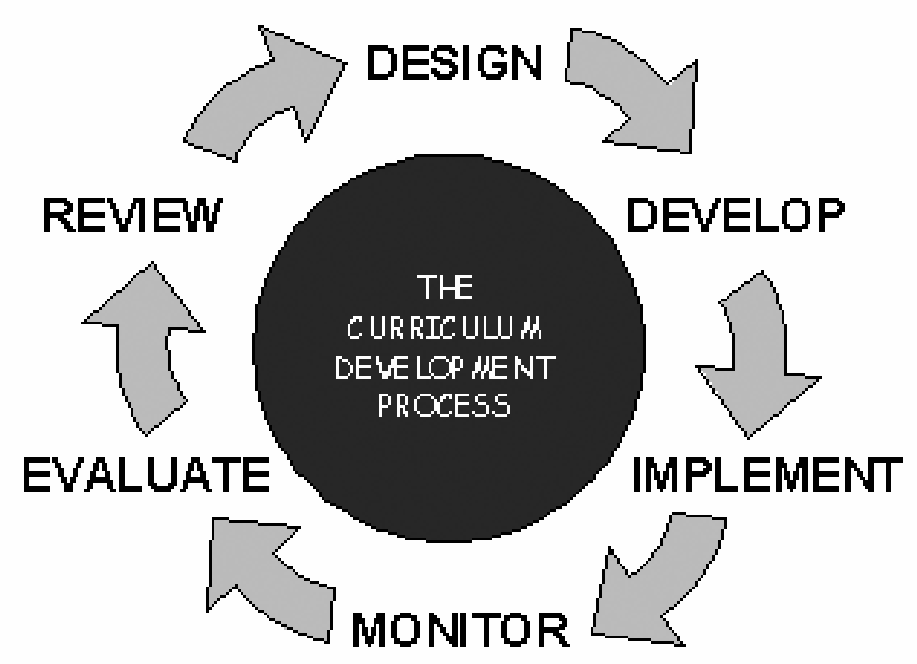

Figure. 1. Curriculum formation process.

Source: Ministry of Education and Culture of the Republic of Indonesia, 2019.

Starting from 1947 to present, Indonesia has .undergone 9 (nine) curriculum changes, all of which were developed based on the objectives of Pancasila and the 1945 Constitution, where can be described as follows:

a) Curriculum 1947, 1952, 1964, and 1968

At this time, the focus of the government was to replace the Dutch era curriculum, by incorporating elements of local characteristics and culture to suit the purpose of forming the Indonesian nation. In 1947, the curriculum was named the 1947 Lesson Plan which focused on 3 (three) main things, which are teaching classes, meeting times per week, and teaching materials. This curriculum was the first to change the Dutch curriculum system which still divided education access based on social class, ethnicity and religion so that it did not reflect the personality of the Indonesian nation.

Of course, with such a very concise arrangement, improvements are needed to pursue wider and better access to the education. Then, the standardization of teaching material is implemented, so that the teaching material provided is in accordance with the daily lives of students. This curriculum is developed in the year of 1952, so it's called the 1952 Unraveled Learning Plan. This curriculum also added several indicators of learning success, which are teaching classes, meeting time per week, teaching topics, moral lessons, and values. After more than a decade, in the year of 1964, the government revise the curriculum, by adding additional principles of patriotism and religious lessons, where at this time the focus of the development of teaching students began to be included, namely intelligence, emotional, psychological, and physical students, in general the curriculum was still the previous curriculum.

The rapid change in education curriculum was initiated in the year of 1968. The government creating a new formed curriculum, which relatively different than 
before, focusing on improving the quality of the students. Since the implementation of the 1968 curriculum, moral education has been infiltrated with the spirit of Pancasila with the aim of fostering the physical and psychological aspects of students in order to foster a sense of nationalism.

b) Curriculum 1975, 1984 and 1994

Starting from the 1975 curriculum development, there is a teaching focus, called the development of knowledge or abilities. It was at this time that a vocational school was initiated that focused on students' physical abilities according to their interests and talents, on the other hand, this curriculum also began to use psychological motoric analysis on students. In order to revise the 1975 curriculum, which was deemed unsuccessful in meeting the demands, latest knowledge and technology during that time, the government revised the curriculum by releasing the 1984 curriculum which emphasized on CBSA (Active Student Learning Method).

The revision of the 1984 curriculum was launched in 1994. The difference from this curriculum compared to the previous curriculum is the change in the system from the semester system to the quarter system. The focus of this curriculum is quite broad, from the meaning of the teaching and learning process, the communicative approach, to the changes in the teaching and learning system based on the context of behavior. Students. Because it is too broad, this is a boomerang from this curriculum itself because it makes students hard to understand the subjects, because of too many approaches, too many subjects, and too much substance from each subject.

c) Competency-Based Curriculum (KBK), 2004

The KBK curriculum is an response to the change in the government organization, from the centralized to the decentralize government system, in accordance with Laws No. 22 and 25 of 1999 on Regional Autonomy. At this time, the curriculum was made based on the competence of students in order to compete at the global level, where the changes to this curriculum are consists of 3 (three) main elements that underlie these global competencies, which are selection of student field competencies, indicators of competency achievement, and development of the education system based on regionalism system.

The effectivity of this curriculum is improved by issuance of the Minister of Education Regulation No. 232 / U.2000 which states that teachers are only facilitators. Then, that regulation is elaborated through Government Regulation Number 25 of 2000 which states that there are 4 (four) national education standards, consists of: competency standards, basic competencies, subjects, and student achievement indicators. Based on these rules, the minimum score for each student competency begins, the value is further divided into 3 (three) tiered standards, which are Graduate Competencies, General Competencies, and Basic Competencies.

d) KTSP, 2006

The KTSP curriculum actually has similarities with the KBK curriculum, the only difference is that the KBK is determined by the central government, while the 
KTSP is prepared by the school itself independenly. In the essence, KTSP is used to standardize the teaching and learning process that is determined and audited by the National Education Standards Agency (BNSP), where these standards are: teaching material standards, teaching and learning process standards, graduate standards, and education standards for educators, standard facilities and supporting infrastructure. Teaching and learning activities, management standards, cost standards, and education assessment standards.

In addition to the established standards, there are KTSP teaching standards in the form of: Focusing on the potential, processes, needs and interests of students' talents, differences and integration, responsive to scientific development, relevant to everyday life, comprehensive and sustainable, long-term use. Meanwhile, there are teaching components in the form of: educational objectives, structure and teaching materials, education calendar, syllabus, and education implementation plan (RPP).

e) Curriculum 2013

The 2013 curriculum is the latest version of the previously implemented KTSP curriculum, where the vision of this curriculum is to create a productive, creative, and effective generation of Indonesia through strengthening behavior, skills and knowledge. The difference between the 2013 curriculum and the KTSP is only in the standardization of the education syllabus, where in the KTSP the syllabus is developed by the school itself, but in the 2013 curriculum the syllabus was developed by the Ministry of Education, where teachers only need to develop educational materials and teaching methods to optimize learning.

That is how the development of education in Indonesia from the postindependence era to the latest. By understanding the development of the curriculum, it can be understood how the development of a country's education world is in line with market growth, global competence and the demands of the times.

\section{Formal and Informal Education Pathways}

Education as a means of developing human capital in a country itself has pathways in the form of formal and informal education. Formal education is a tiered education that is required to be taken by every member of society in accordance with applicable laws and regulations, where there are institutions that provide formal education levels with curricula that have been standardized by the relevant Ministries / Institutions, where these levels are: TK / RA, SD / MI, SMP / MTs, SMA / MA, SMK / MAK, Higher Education (Academies, Polytechnics, Colleges, Institutes and Universities).

Meanwhile, formal education according to Law no. 20 of 2003, is an education pathway whose goal is to replace, add to and complement formal education and be outside the formal education pathway whose implementation is carried out in stages. Non-formal education institutions can be in the form of Course / Training Institutions, Study Groups, Community Learning Activity Centers, and Ta'lim Council, as well as similar educational units. Then, non-formal education is education carried out by utilizing family and environmental channels, with outputs are knowledge of religion, character, ethics, courtesy, morals and social skills. 
According to (Wahyuni, 2016), formal education is education that focuses on expertise and knowledge development, so it is expected to have an impact, especially in terms of science and technology development and work specialization which will have a significant impact on human capital development as one of the points of economic growth. Meanwhile, informal education plays a very important role in equitable education, especially for those who do not / do not meet the requirements for formal education. Where informal education focuses more on developing the potential of students with an emphasis on mastering knowledge and functional skills, where the development of life skills and job training is the focus of informal education, this equity makes the number of workforce increase, and is one aspect of human capital investment. On the other hand, non-formal education is very important to shape the personality of students in these formal and informal channels. Of course, the pathways of formal and informal education require discipline, ethics, and social skills that are obtained from non-formal education.

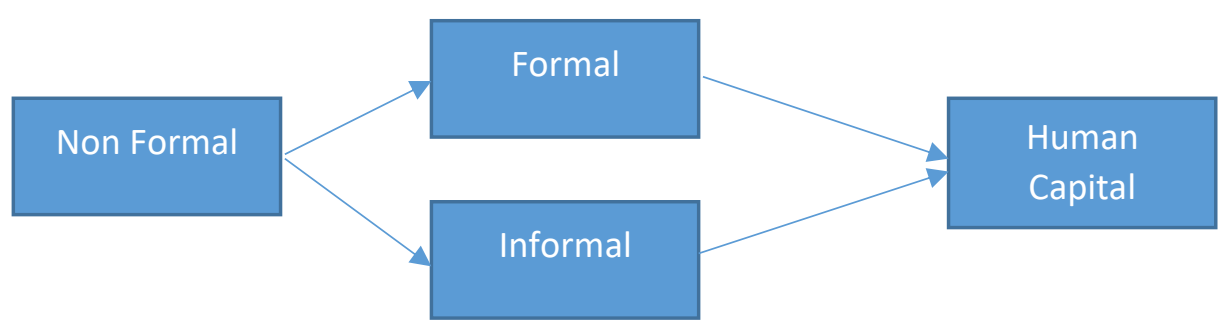

Figure. 2. The relationship between non-formal, formal, and informal education in the process of developing Human Capital of a country. Source: The Impact of Formal and Informal Institutions on Economic Growth. 2011.

It can be concluded that non-formal, informal, and formal education are closely related, with the main output being an increase in the quality of human capital in order to accelerate the economic growth of a country. In accordance with Solow's theory of economic growth, capital and human capital are the main factors that affect output and affect economic growth.

\section{The Impact of Education on Economic Growth.}

The existence of economic theory is largely determined by its ability to explain actual economic phenomena. Theoretical analysis and empirical evidence have always been twin activities carried out coherently in every field of science including economics (Henderson and Quant, 1980). Economic growth is generally a process of increasing output per capita in the long run related to the process, output per capita, and the long run. Growth as a process means that economic growth is not a picture of the economy at one time or a short period of time. Economic growth is related to output per capita, meaning that it must pay attention to two things, namely total output or Gross Domestic Product (GDP) and population, because per capita output is the total output divided by the population. Meanwhile, growth related to long-term aspects means that the increase in output per capita must be seen in a long period of time, for example 10 or 20 years and even longer.

Smith (1776), in his book 'An Inquiry into the Nature and Causes of the Wealth of Nations', put forward a very famous theory, namely regarding specialization and the 
division of labor. Stock capital $(K)$ has two effects on the level of total output $(\mathrm{Q})$, namely the direct effect and the indirect effect. $\mathrm{K}$ has a direct effect on $\mathrm{Q}$ because the addition of $\mathrm{K}$ followed by the increase in labor $(L)$ will increase $Q$. Mathematically, it is written as follows: $Q=f(K, L)$.

The indirect effect of $\mathrm{K}$ on $\mathrm{Q}$ is an increase in per capita productivity through the possibility of a higher specialization and division of labor (specialization and division of labor). The greater the capital (K) used, the more likely it is to specialize and divide labor, and in turn, the productivity per worker will be increased.

Increased productivity comes from the following matters. First, specialization will actually improve the skills of each workforce in doing their job. Second, through the work division system will save time, when workers switch from one type of work to another job. Third, the discovery of machines with better technology, which simplifies and speeds up the work process.

From the above description, it can be interpreted that the continuous increase in the stock of capital $(\mathrm{K})$ by assuming that labor $(\mathrm{L})$ is always fulfilled, will also be followed by an increase in total output $(Q)$ continuously until it reaches the upper limit of the resource. When the limit of these resources has been reached, the process of economic growth stops, which is called a stationary state. In this position, all factors of economic growth stop; capital growth ceases, population growth ceases, and output growth ceases.

\section{The Role of Education in Economic Growth}

Education cannot be separated from economic problems, either directly or indirectly (Agasisti \& Bertoletti, 2020; Ganegodage \& Rambaldi, 2011; Jalil \& Idrees, 2013). Various academic studies and empirical research have proven its validity. Alhumami (2004) states that education not only produces quality human resources, possesses knowledge and skills, and masters technology, but also fosters a business climate that is healthy and conducive to economic growth. This encourages every citizen to be independent in a fair and healthy entrepreneurship. In other words, participating in an active contribution to development, through productivity can increase income and ultimately boost economic growth (Brende, 2014; Huggins \& Thompson, 2015; Lee et al., 2004; Pradhan et al., 2020).

Investments in education are not only beneficial for individuals, but also for the business community and the general public (Capelleras et al., 2019; Pegkas et al., 2019). Educational attainment at all levels will undoubtedly increase people's income and productivity. Education is a path to progress and the achievement of social and economic welfare, while the failure to develop education will give rise to various crucial problems: unemployment, crime, drug abuse, and welfare dependency which are a socio-political burden on the government (Hjern, 2004; Molnar et al., 2016; Saadé et al., 2012). The term welfare dependency is a condition where a person or household is highly dependent on welfare benefits from the government for their income in the long term, and without it they will not be able to meet the costs of daily living. The term is highly controversial, often carrying the derogatory connotation that the recipient is unwilling to work (Bane and Ellwood, 1996).

The United Nations Development Program (UNDP) since the 1990s has clearly explained the importance of human development, where human quality is the true wealth of the nation. It was also stated that the main objective of development is to create an 
enabling environment for its people to enjoy a long life, a healthy body, and lead a productive life. The report explains that human-centered development is promoted through the affirmation that human development is the ultimate end of development, while economic growth is the principal means of achieving that development goal.

It is increasingly clear that the intended expansion of options is at the process level and at the level of the end result of development. The expansion of options at the process level is provided for humans in their role as actors of development, while the expansion of options in the level of the final product is provided for humans in their role as connoisseurs of development.

Human development is basically an effort to build human capacity, regardless of whether they are poor or rich, through improving health, knowledge and skills, as well as utilizing their abilities or skills. Qureshi (2010) states that the concept of human development is much broader than the concept of economic development which emphasizes economic growth, basic needs, social welfare, or human resource development. human resource development).

The descriptions above further strengthen the human-centered development paradigm, which places humans as the ultimate goal of development and not only as a development tool. To realize the intended development goals, there are four main things (productivity, equality, sustainability, and empowerment) that must be considered as a key component of human development, as described in the following UNDP.

First, productivity, means that a productive human being will be able to generate income for himself and for his family and for his area. Therefore, economic growth is part of the human development model, and is an endogenous variable that will affect the human development index.

Second, justice (equality), means that humans as social beings must have the same opportunity to live a better life. Monopolistic practices, such as economic monopoly and political monopoly, must be abolished through democratic arrangements. Everyone can choose what is best for their life as long as it does not violate the rules of the game that have been mutually agreed upon constitutionally and democratically.

Third, sustainability, which means that the available resources can be used wisely for the benefit of humans, both present and future generations. The present generation must be aware of and ensure the availability of the resources that future generations both need. Non-renewable resources are only used sparingly while imposing an obligation for the current generation to find alternative sources of substitute resources from renewable resources.

Fourth, empowerment means that it is human nature that does not always have the ability to access equal opportunities and opportunities for the welfare of themselves and their families. Because it is necessary to have empowerment so that human development can be done by everyone, not just for everyone. With empowerment, everyone can participate fully in decision making and the process affects their well-being.

Economists have agreed that the human resource (HR) of a nation, not just physical capital or material resources, is the most determining factor in the character and speed of a nation's social and economic development (Todaro and Smith, 2009). This process has at least two basic requirements; first, the existence of human resources that 
are both quantity and quality capable of processing and utilizing other resources in the development process, and second, the existence of a market that supports transactions of goods and services produced in the development.

It is almost certain that the interaction between education output and labor demand will always experience gaps. One reason is because education and employment are two entities that have different domains and characteristics. The difference that is striking and always creates inequality is the nature of education which is a demographic factor, while employment is an economic factor and part of the purpose of education itself.

Demographic factors, in the sense that education which serves the community evenly and fairly everywhere, are related to Indonesia which is constrained by the size of an archipelago and must provide equal access and equality. The economic factor refers to employment which is the optimization of choice, in this case educated and skilled workers. Whenever there is a gap between education and the need for employment is widening, this will threaten individual productivity and further affect overall growth.

Therefore, the government must have projections on the demand for manpower and in any fields to support future development. This is to reduce the occurrence of market failures when the free market functions or fails to provide an efficient allocation of resources (market failure), so as to realize an equilibrium or balance between demand and demand for labor.

\section{Endogenous Growth Model Analysis}

In the GDP approach, which is a function of production factors consisting of capital, labor (both quantity and quality that can be represented by education), technology, and the quality of society (which can be represented by education). GDP will increase or economic growth will occur if these production factors increase. By using the required secondary data and applying the econometric method, it can be seen the role of each production factor, including the production factor in the form of education (either in general or vocational or by education level) of labor and society, on economic growth.

Lewis (1956), defines that the factors that influence growth are labor associated with the use of capital. With a certain stock of capital, the marginal product of labor (MPL), starting from a certain point, decreases. In line with Lewis, explaining economic growth is a causality formula between investment, savings, capital, and population to influence output (Ray, 1998).

Kaldor in Djoyohadikusumo (1994) states that the long-term growth process is directed at sectoral growth which includes the primary production sector and the secondary sector, while the tertiary sector is considered a function of industrial development. In line with Kaldor's opinion, Lucas (in McMahon, 2002) argues that what affects economic growth is capital and labor with quality elements included in it. Solow (1956), stated that the dominant factors affecting economic growth are capital and labor.

In terms of the human capital variable $(\mathrm{N})$, in this context it will be seen not only the number which tends to increase from year to year but also the quality improvement. Of course, one of the ways to improve the quality of human resources can be achieved through education, both formal and non-formal and informal education. The variable of physical capital $(\mathrm{K})$ is the value of capital or production equipment used in the production process to produce goods and services. This variable is somewhat difficult to measure, 
while it can be used as a proxy for the gross domestic fixed capital formation (PMTDB). The community education variable (ha) is a description of the level of education that has been obtained or has been achieved by all people in a particular area. This variable can be approximated by the average level of education of the population in an area.

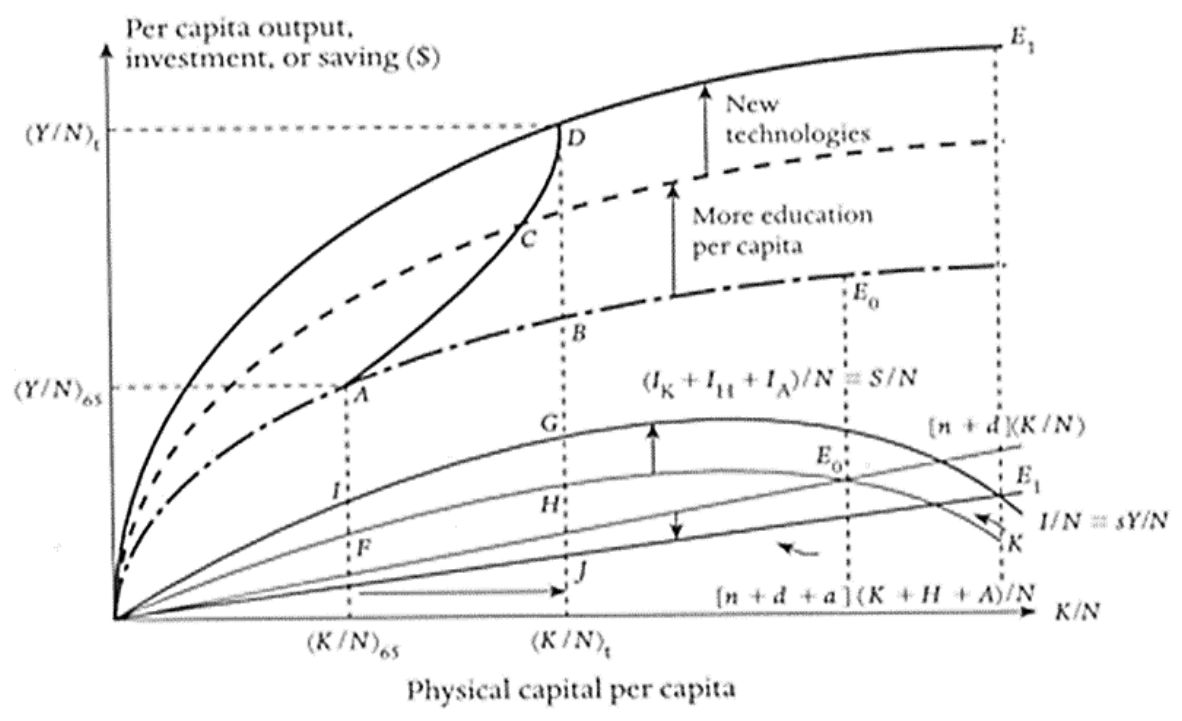

Figure 3. The theoretical explanation of education in economic growth. Source: The Impact of Education to the Economic Growth. Journal of Indonesian Economy and Business. Volume 28, Number 1, 2013, 23 - 44.

The significance of public education for economic growth in the model comes from the understanding that the more advanced the level of public education is, then The community concerned will be more responsive, where when the stock of physical capital $(\mathrm{K})$ increases faster than the number of people $(\mathrm{N})$, physical capital deepening occurs, increasing $\mathrm{K} / \mathrm{N}$ along the horizontal axis. However, if there is no increase in the education and skills of the workforce, this physical capital deepening separately faces diminishing returns, as shown from $A$ to $B$. This results in slower output growth that eventually reaches a steady state.

With the increase in investment in human resources " $\mathrm{H} / \mathrm{N}$, the production function which is only expressed as a function of physical capital on the horizontal axis shifts upwards. In an endogenous growth model with increasing returns to scale, the dynamic time path in the short and medium term is from $A$ to $C$, due to capital deepening. The slope moves upward, so that the per capita output $\mathrm{Y} / \mathrm{N}$ grows and grows with increasing returns without being financed through taxes (S). Investment in physical capital and investment in human capital equals per capita saving.

Physical capital deepening is a barrier to medium term, even if it is in the long term. Total investment in physical capital is increased by investment in human capital through education and new technology that is greater than zero, total capital deepening is shown by the line through $\mathrm{G}$ instead of $\mathrm{H}$.Investment policies in human capital and knowledge will shift total investment per capita from $F$ to $I$ and increasing total savings and the stock of 
SHEs: Conference Series 4 (3) (2021) $17-31$

human capital. Output and income in the medium term will grow not from A to B but from A to $\mathrm{D}$.

In the long run, various investments are needed to compensate for depreciation and keep pace with population growth. With the actual investment in $G$ and subtracting from $J$ to keep the per capita capital stock constant, total capital deepening will continue until a long term solution is reached in $\mathrm{E}$. This confirms that education is very much needed in achieving economic growth, where first, education produces specializations that will increase the efficiency and effectiveness of economic activities. Second, education increases the ability to use new technology so that it can significantly boost economic growth. Third, education prevents Indonesia from falling into a middle income trap, which is a stagnant condition so that economic growth tends to remain stable.

\section{CONCLUSION}

Education which consists of 3 (three) main lines, namely formal, informal and nonformal education have complemented each other to produce human capital development. The pattern of education following the trend of developments in global economic conditions has been started since the post-independence era, which began with the development of a simple 1947 teaching plan curriculum in accordance with the country's economic conditions at that time which was still in the developing stage. This continues until the 2013 curriculum which emphasizes global competence in accordance with the global economy which requires this. Economic growth itself is needed by a country to achieve maximum economic growth, especially to avoid a steady state position, when all economic resources have been used. According to the theory of Solow economic growth, economic growth $(Q)$ is influenced by capital $(K)$ and workers $(L)$, where the accumulation factor (f) in the form of education as human capital investment can increase mastery of technology and accelerate more effective and efficient work methods, which will increase the output of a country's economic activity calculated based on GDP, so that it is not trapped in a steady state condition. 


\section{REFERECES}

Abel, J. R., \& Gabe, T. M. (2011). Human capital and economic activity in urban America. Regional Studies. https://doi.org/10.1080/00343401003713431

Agasisti, T., \& Bertoletti, A. (2020). Higher education and economic growth: A longitudinal study of European regions 2000-2017. Socio-Economic Planning Sciences. https://doi.org/10.1016/j.seps.2020.100940

Benos, N., \& Karagiannis, S. (2016). Do education quality and spillovers matter? Evidence on human capital and productivity in Greece. Economic Modelling. https://doi.org/10.1016/j.econmod.2016.01.015

Bonaccorsi, A., Daraio, C., \& Simar, L. (2006). Advanced indicators of productivity of universitiesAn application of robust nonparametric methods to Italian data. Scientometrics. https://doi.org/10.1007/s11192-006-0028-x

Boon, C., Eckardt, R., Lepak, D. P., \& Boselie, P. (2018). Integrating strategic human capital and strategic human resource management. International Journal of Human Resource Management. https://doi.org/10.1080/09585192.2017.1380063

Brende, K. S. S. B. (2014). The Global Competitiveness Report. In World Economic Forum Reports 2014. https://doi.org/ISBN-13: 978-92-95044-73-9

Cailhol, J., Craveiro, I., Madede, T., Makoa, E., Mathole, T., Parsons, A. N., Van Leemput, L., Biesma, R., Brugha, R., Chilundo, B., Lehmann, U., Dussault, G., Van Damme, W., \& Sanders, D. (2013). Analysis of human resources for health strategies and policies in 5 countries in Sub-Saharan Africa, in response to GFATM and PEPFAR-funded HIV-activities. Globalization and Health. https://doi.org/10.1186/1744-8603-9-52

Capelleras, J. L., Contin-Pilart, I., Larraza-Kintana, M., \& Martin-Sanchez, V. (2019). Entrepreneurs' human capital and growth aspirations: the moderating role of regional entrepreneurial culture. Small Business Economics. https://doi.org/10.1007/s11187017-9985-0

Cohendet, P., Grandadam, D., \& Simon, L. (2011). Rethinking urban creativity: Lessons from Barcelona and Montreal. City, Culture and Society. https://doi.org/10.1016/j.ccs.2011.06.001

Faggian, A., Partridge, M., \& Malecki, E. J. (2017). Creating an Environment for Economic Growth: Creativity, Entrepreneurship or Human Capital? International Journal of Urban and Regional Research. https://doi.org/10.1111/1468-2427.12555

Ganegodage, K. R., \& Rambaldi, A. N. (2011). The impact of education investment on Sri Lankan economic growth. Economics of Education Review. https://doi.org/10.1016/j.econedurev.2011.08.001

Ghulam, Y., \& Mousa, W. I. (2019). Estimation of productivity growth in the Saudi higher education sector. Technological Forecasting and Social Change. https://doi.org/10.1016/j.techfore.2019.119741

Haller, S., Serbanati, A., Bauer, M., \& Carrez, F. (2013). A domain model for the internet of things. Proceedings - 2013 IEEE International Conference on Green Computing and Communications and IEEE Internet of Things and IEEE Cyber, Physical and Social Computing, GreenCom-IThings-CPSCom 2013. https://doi.org/10.1109/GreenComiThings-CPSCom.2013.87

Hepp, P., Hinostroza, J. E., Laval, E., \& Rehbein, L. (2004). Technology in Schools: Education, ICT and the Knowledge Society. World Bank Education Advisory Service.

Hjern, A. (2004). Illicit drug abuse in second-generation immigrants: A register study in a national cohort of Swedish residents. Scandinavian Journal of Public Health. https://doi.org/10.1080/14034940310001677 
Huggins, R., \& Thompson, P. (2015). Entrepreneurship, innovation and regional growth: a network theory. Small Business Economics. https://doi.org/10.1007/s11187-0159643-3

Ingham, J. (2007). Strategic human capital management: Creating value through people. In Strategic Human Capital Management: Creating Value through People. https://doi.org/10.4324/9780080468259

Jalil, A., \& Idrees, M. (2013). Modeling the impact of education on the economic growth: Evidence from aggregated and disaggregated time series data of Pakistan. Economic Modelling. https://doi.org/10.1016/j.econmod.2012.11.035

Kurilovas, E., Kubilinskiene, S., \& Dagiene, V. (2014). Web 3.0 - Based personalisation of learning objects in virtual learning environments. Computers in Human Behavior. https://doi.org/10.1016/j.chb.2013.07.039

Lee, S. Y., Florida, R., \& Acs, Z. J. (2004). Creativity and entrepreneurship: A regional analysis of new firm formation. Regional Studies. https://doi.org/10.1080/0034340042000280910

Menolli, A. (2015). Social software and learning. In Organizational Learning: Individual Differences, Technologies and Impact of Teaching.

Molnar, B. E., Goerge, R. M., Gilsanz, P., Hill, A., Subramanian, S. V., Holton, J. K., Duncan, D. T., Beatriz, E. D., \& Beardslee, W. R. (2016). Neighborhood-level social processes and substantiated cases of child maltreatment. Child Abuse and Neglect. https://doi.org/10.1016/j.chiabu.2015.11.007

Pegkas, P., Staikouras, C., \& Tsamadias, C. (2019). Does research and development expenditure impact innovation? Evidence from the European Union countries. Journal of Policy Modeling. https://doi.org/10.1016/j.jpolmod.2019.07.001

Ployhart, R. E., Nyberg, A. J., Reilly, G., \& Maltarich, M. A. (2014). Human Capital Is Dead; Long Live Human Capital Resources! Journal of Management. https://doi.org/10.1177/0149206313512152

Pradhan, R. P., Arvin, M. B., Nair, M., \& Bennett, S. E. (2020). The dynamics among entrepreneurship, innovation, and economic growth in the Eurozone countries. Journal of Policy Modeling. https://doi.org/10.1016/j.jpolmod.2020.01.004

Saadé, R. G., Morin, D., \& Thomas, J. D. E. (2012). Critical thinking in E-learning environments. Computers in Human Behavior. https://doi.org/10.1016/j.chb.2012.03.025

Schultz, T. W. (1961). Investment in Human Capital: Reply. The American Economic Review.

Soukiazis, E., \& Antunes, M. (2011). Is foreign trade important for regional growth? Empirical evidence from Portugal. Economic Modelling. https://doi.org/10.1016/j.econmod.2011.02.023

Sözbilir, F. (2018). The interaction between social capital, creativity and efficiency in organizations. Thinking Skills and Creativity. https://doi.org/10.1016/j.tsc.2017.12.006

Storper, M., \& Scott, A. J. (2009). Rethinking human capital, creativity and urban growth. Journal of Economic Geography. https://doi.org/10.1093/jeg/lbn052

Stošić, L., \& Stošić, I. (2015). Perceptions of teachers regarding the implementation of the internet in education. Computers in Human Behavior. https://doi.org/10.1016/j.chb.2015.07.027

Wahyuni, S. (2016). Curriculum Development In Indonesian Context The Historical Perspectives And The Implementation. UNIVERSUM. https://doi.org/10.30762/universum.v10i1.225

Wright, P. M., \& Mcmahan, G. C. (2011). Exploring human capital: Putting "human" back 
International Conference of Economics Education and Entrepreneurship (ICEEE 2020)

SHEs: Conference Series 4 (3) (2021) $17-31$

into strategic human resource management. Human Resource Management Journal. https://doi.org/10.1111/j.1748-8583.2010.00165.x

Zhang, X., Ordóñez De Pablos, P., \& Zhou, Z. (2013). Effect of knowledge sharing visibility on incentive-based relationship in Electronic Knowledge Management Systems: An empirical investigation. Computers in Human Behavior. https://doi.org/10.1016/j.chb.2012.01.029 